the pessimistic feeling, not uncommon at that time, that all the interesting things had been discovered, and all that was left was to alter a decimal or two in some physical constant. There never was any justification for this feeling, there never were any signs of an approach to finality in science. The sum of knowledge is at present, at any rate, a diverging not a converging series. As we conquer peak after peak we see in front of us regions full of interest and beauty, but we do not see our goal, we do not see the horizon; in the distance tower still higher peaks, which will yield to those who ascend them still wider prospects, and deepen the feeling, whose truth is emphasized by every advance in science, that "Great are the Works of the Lord."

J. J. THOMSON

\section{ROBERT EDWARDS CARTER STEARNS}

Dr. Robert Edwards Carter Stearns died at Los Angeles, Cal., July 27, in his eightythird year. $\mathrm{He}$ was a native of Boston, Mass., a son of Charles Stearns, and was born February 1, 1827. He was educated in the public schools, followed by a course of mercantile training, and from his earliest years evinced a deep love of nature, fostered by his father, with whom similar tastes led to a degree of comradeship in rambles and hunting expeditions which he always remembered with appreciation. The boy had an unusual artistic ability, and, though his early avocations were services in a bank and on a farm, when only twenty-two years of age he painted a panorama of the Hudson River from the mouth of the Mohawk to Fort William, which he exhibited with much success. He turned his attention to mining, explored the coal fields of southern Indiana, and in $\mathbf{1 8 5 4}$ was appointed resident agent of several copper mines in northern Michigan, on Lake Superior. In 1858 he went to California, where he became a partner in the large printing establishment of a brother-in-law of his wife, in San Francisco. This firm published the
Pacific Methodist, a weekly religious paper, and in the troubled times preceding the civil war the reverend editor of this journal was obliged to visit the east. Stearns was requested to fill this place during his absence. The fate of California hung in the balance, many of the immigrants from the southern states urged independence for that territory when hostilities broke out. Stearns took the responsibility of making his paper an enthusiastic advocate of the union cause, and to this call and the eloquence of Thomas Starr King, old Californians believed the decision of the people to stand by the Union in that struggle was due in no small degree. Through the influence of Justice Field, Stearns was appointed deputy clerk of the supreme court of California in 1862, a post which he resigned in the following year to accept the secretaryship of the State Board of Harbor Commissioners, which he was obliged to resign some years later on account of ill health. Coming to the east, he made one of a party, comprising besides himself the late Dr. William Stimpson and Col. Ezekiel Jewett, for the exploration of the invertebrate fauna of southwestern Florida, during which large collections were made for the Smithsonian Institution. He returned to California, and in 1874 was elected secretary of the University of California, being the business executive of that institution under the presidency of the late Dr. Daniel C. Gilman. He served in this capacity for eight years with great approval, and, when ill health again obliged him to retire from service, the university as expressive of their sense of his services to the cause of education in California, and in recognition of his scientific attainments, conferred upon him the degree of doctor of philosophy. Returning to the east after the death of Mrs. Stearns, he was engaged in researches for the U. S. Fish Commission in 1882, was appointed paleontologist to the U. S. Geological Survey by Major Powell in 1884, and assistant curator of mollusks in the National Museum by Professor Baird. His collection of mollusca was acquired by the museum. Age and infirmity obliged him to return to the more genial climate 
of California in 1892, where he settled in Los Angeles, continuing, as his strength permitted, his researches into the malacology of the $\mathrm{Pa}$ cific coast. He married March 28, 1850, Mary Anne Libby, daughter of Oliver Libby, of Boston, and is survived by a daughter.

Dr. Stearns was an earnest student of mollusks from boyhood; his early experience led him to interest himself in horticulture and landscape gardening, and his ability in this line is attested by the beauty of the university grounds at Berkeley, which were developed under his superintendence. His knowledge of the Pacific coast mollusca was profound, and a long list of papers on this topic and on the shells of Florida was the result. He also contributed many papers on various branches of horticulture and gardening to the California periodicals devoted to this subject. He was an enthusiastic supporter of the California Academy of Sciences in its early days, and, after the earthquake of 1868 , when disaster threatened the society, he, with Professor J. D. Whitney and a few other friends, stood between it and dissolution. He was a member of numerous scientific societies at home and abroad, and of the Sons of the Revolution.

Dr. Stearns was a man of sanguine temperament, with a lively sense of humor and high moral character. His reading was wide, his learning never obtrusive, his interest in art, literature and all good causes, intense. He was a staunch friend and, for a righteous object, ever ready to sacrifice his own material interests. His services to Californian science will keep his memory green.

WM. H. DALL

\section{SCIENTIFIC NOTES AND NEWS}

AT a meeting of the Paris Academy of Sciences on August 18, the permanent secretary gave a eulogy of Professor Simon Newcomb, who was a foreign associate of the academy.

In the last issue of ScIEnce it was noted that at the celebration of the five-hundredth anniversary of the University of Leipzig the degree of doctor of medicine was given to Professor E. B. Wilson, of Columbia University, and the degree of doctor of philosophy to Pro- fessor Jacques Loeb, of the University of California. The degree of doctor of philosophy was also given to Professor A. A. Michelson, of the University of Chicago. There were in all five degrees given to Americans, more than to the citizens of any foreign country except Austria. The two other degrees were to Mr. Roosevelt and Professor J. W. Burgess, of Columbia University.

Clark University will hold its second decennial celebration from September 6 to 11 , the exercises being under the auspices of the department of psychology and the department of pedagogy and school hygiene. Those from abroad who will give lectures are Professors L. William Sterns, of Berlin; Dr. C. G. Jung, of Zurich; Dr. Leo Bergerstein, of Vienna, and Dr. Sigmund Freud, of Vienna. Among those from America who give lectures are Dr. Ellsworth Brown, Professor E. B. Titchener, Professor Franz Boas, Professor H. S. Jennings and Professor Adolf Meyer.

The Paris Academy of Sciences has decided to signalize its appreciation of work in aeronautics by devoting $\$ 4,000$ to striking gold and enamel medals which will be presented to foreign and French aeronauts. Medals will be awarded to the Wright brothers, and to MM. Bleriot and Voisin.

IT is stated in Nature that the Cracow Academy of Soiences has awarded the Nicolas Copernic prize, amounting to 1,000 crowns, to M. Jean Krassowski, of Cracow, for his treatment of the question, "A l'aide de la méthode de M. A. Schuster, examiner la question si les périodes des variations des latitudes, indiquées par MM. Chandler, Kimura, ete., sont réelles ou non." The Constantin Simon prize, of 900 crowns, for a work in the Polish language on mathematics or physics, has been adjudicated to M. Stanislas Zaremba, for his book " Exposé des premiers Principes de la Théorie des Nombres entiers."

THE Paris correspondent of the Journal of the American Medical Association reports that the Academy of Sciences has awarded three prizes of $\$ 500$ (2,500 francs) each, one to Dr. Neumann for his researches on the family of the ixodidæ and on the various groups of para- 